\section{SOI: 1.1 TAS DOI: 10.15863 /TAS \\ International Scientific Journal Theoretical \& Applied Science}

Mirkomil Axmadovich Atavullaev

Senior scientific researcher

Department of National idea

Faculty of social sciences

National University of Uzbekistan

Tashkent, Uzbekistan naumenko06@mail.ru

Year: 2017 Issue: 02 Volume: 46

Published: 19.02.2017 http://T-Science.org

SECTION 30. Philosophy.

\title{
LEGAL CULTURE AND PHILOSOPHICAL AND LEGAL ASPECTS OF DEMOCRATIC RENEWAL IN UZBEKISTAN
}

\author{
Abstract: In this article the legal aspects related to the phenomenon of democratic renewal, legal culture, \\ regulatory, legal, social and communicative and prognostic functions associated with are considered and opened. \\ Key words: legal culture, regulation, axiology, adaptation, normative, socialization, education, law, spiritual \\ propaganda. \\ Language: English \\ Citation: Atavullaev MA (2017) LEGAL CULTURE AND PHILOSOPHICAL AND LEGAL ASPECTS OF \\ DEMOCRATIC RENEWAL IN UZBEKISTAN. ISJ Theoretical \& Applied Science, 02 (46): 59-62. \\ Soi: http://s-o-i.org/1.1/TAS-02-46-13 Doi: crossef https://dx.doi.org/10.15863/TAS.2017.02.46.13
}

\section{Introduction}

Legal culture, not just legal knowledge, legal awareness and legal behavior is not the sum of the social, legal and political assets on the basis of democratic values update. For the understanding of the legal culture, as well as the value of its social, political and legal understanding of the nature and location of the assets.

\section{Materials and Methods}

According to experts, the categories of "human rights" and "culture" etymological point of view, the fact that the sociological, even if they are interpreted as different events, they can be opened by means of a link between human rights. This concept of a scientific basis, but they are legal culture, particularly in the social, political, philosophical, axiological fields can not deny as phenomenon. Lawyers also recognize that sometimes unconscious. For example, legal scientist H.Boboev writes: "The broad philosophical sense, that is, people impose their difference in other people access to social relations and relations to other people aware of the need for the construction of a legal laws or the device will appear in his legal culture" [1; 178]. this continues the professor H.Boboev writes: "the right to equal legal norms (ie the positive law - M.A.), which is the highest legal norms and laws. civilized values (moral and material wealth M.A.). Therefore, the legal culture of society reflected in its wealth, the wealth level of legal culture of the period in accordance with the requirements and needs of the community $[1$;
178]. According to the scientist, "the legal culture and legal cultural and social wealth as a form represents the needs and requirements ... you know, the creative needs of specific interests than the interests of different strata of the population. "At the same point of view, the people, the people, as subjects of the rights of those categories. Therefore, the legal culture mark the national population, their participation in creating a legal and cultural wealth ... It does not have the legal and cultural creativity, the legal culture and the rule of law [1;179-180]. This definition of the nation as the subjects of the legal culture of the population, who considered the legal question of who are the objects of culture as well. If the object of the legal culture of society, that is, people, people, people and institutions, it is again the subject of objects as logically normal. At the same time, society, people, people, people are subject, the object can not be. Logically so. However, people, people, people of different layers, they are all the same imagination and knowledge, human special knowledge experiences layer (intellectuals, lawyers, scientists, legal institutions and their staff, specialists of the judicial system, police departments, personnel working in them, etc.) to popularize legal knowledge, understanding of how the human form and the norms of behavior and skills. It is at this point of the community, the nation, the people, are the subjects of the legal culture, as well as objects. However, such a dualistic approach to diminish the role of private institutions and companies. The formation of the 
legal culture actuality and growth that depends on the activity of these institutions. As well as social activities not only differentialization, requires deepening. Legal issues, including the modernization of society through enhancing the legal culture and the highly educated, professional whom you want, place intractable.

Legal culture can be seen as a value in its social functions. U.Tojixonov and A.Saidov includes:

-regulative;

-normative;

-sociologic;

-communicative;

-prognostic [2; 51-52].

These features will continue the existing legal approaches in the literature. But in recent years, which leads to the expansion of the functions of the different approaches to legal culture. Therefore, we grouped lawyer O.Nasriddinova close. Scientist makes the functions of the legal culture:

1. Adaptive function.

2. The educational function.

3 . The educational function.

4. Regulatory function.

5. Integration function.

6. Communicative function.

7. Socialization function.

8. Axiological or socio-cultural values (values) function [3; 19].

Depending on the combination of legal culture and democratic values of their society through these functions is desirable to clarify the impact of the update.

Adaptation of human society and the new social, political and legal compatibility of existence, this means moving to live according to the norms. This is a new historical and cultural paradigms through one of the pressing problems. For example: let's transition to market relations. Although the state has created the necessary legal framework in this regard, block forces are still widespread. This system of local government were common. Researcher N.Nishonova conducted the results of the sociological questions and the answers that the respondents $72 \%$ of small businesses and entrepreneurs who have "prevented the local authorities," $61 \%$ "important opportunity to work," replied [4; 163]. "Do you think that the city, state to attract women and girls to engage in entrepreneurial activity conditions?" The question of Bukhara region respondents $72.0 \%$, Kashkadarya region $74.0 \%$, Ferghana region $59.5 \%$, 50\% city citizens, Khorezm region $36.4 \%$ Samarkand region $26.8 \%$ said "No," he replied. Thus, the system of public administration, citizens and business support calls activity in the host country $[4 ; 161-16]$. Clearly, the adaptation to the requirements of the market economy, the local authorities. As a result, the values of a democratic society, especially in difficult economic management system in the lower level of adaptation to democratic values.

For example, in the Kashkadarya region registered 47 thousand 400 small business and private entrepreneurship, identified one of the 3 thousand 450 are in the ninth almost unavailable. To them to establish their own small businesses, buildings, land acquisition, engineering and communication networks to connect different issues. Worst of all, the various illegal activities of business entities controlled by the authorities involved. In the first half of 2013 on the activities of business entities controlled by the authorities identified 14 illegal checks. In addition, the registration of businesses in a number of areas mentioned in violation of the rights and interests of entrepreneurs in the work of inspectorates [5; 23].

The importance of legal culture and educational function rights phenomenon positive impact on the development of corporate social dogmatic of the general public, who need to be informed. Therefore, the National Programme of "Raise the legal culture in the society" which was adopted on August 29, 1997 to enhance knowledge of the rights of the people, their legal documents, laws adopted in the legislative introduction to the mass media, and the organization of their discussion, etc. noted [6;7-8]. However, this does not document the expected effect. Therefore, the President Shavkat Mirziyoyev "speech at the ceremony dedicated to the 24th anniversary of the adoption of the Constitution of the Republic of the need to get new national program."

Today, promoting the legal culture in the Republic, almost all of the social, educational, educational outreach, community-based organizations, national and cultural centers, communities, academic institutions and others. Today, because of the legal culture of social and educational processes, education is closely to positive results [7; 17-19]. Experts considered, the current state of the legal culture that, since the adoption of the Constitution of the Republic of Uzbekistan and legal values, in accordance with the level of legal culture of the modern constitutional requirements necessary to upgrade. Today, however, there was a need for further improvement of the system of legal education. For government agencies, and non-governmental organizations to coordinate efforts wasted in the process of legal education is not enough. The development of fundamentally new issues, such as the country of origin of the tasks of the present stage of modernization and democratization is essential to resolve the case [8;8].

The legal culture and the authorities, the Ombudsman, the Human Rights Research Center, the center of public opinion indicated, in turn, these institutions will be known to those responses. For example, in 2007 with 8611 applications for citizens to complain to the Ombudsman, in 2011, more than 
11204 people, in 20151100 people. Researcher X.Mamatov say that, 1244 representatives of the central office of the Ombudsman 7367 complaints and 5372 more than half of those who are citizens of Uzbekistan, the Republic 2848tasi girls. Complaints and petitions received 19 penal institutions in 1250 were repeated. The Ombudsman received complaints and petitions under control 2053tasi 1499tasi considered them to resolve 360. [8; 111]. The figures show that, for the protection of the rights and freedoms of its citizens which institutions could apply.

"Electricity in the lobby for three months under the Prime Minister to address more than 218 thousand people. Violations of the right people, expressed dissatisfaction management system of public service, "True, the population of these indicators, the culture does not mean that the executive bodies.

Legal education in all educational process is in need of direct contacts between the subject and the object. Self-legal training, legal awareness of legal education in the most effective format. Unfortunately, the scientific community say something about it, because it remains ignored. Subject-object relations institutions is that they social, political and legal entity responsible for its situation. Therefore, the activities of their demands, legal, educational activities, combined with the activities of the mass media. That is reflected in the media, and legal advocacy work as fast as the population. The community center "Public Opinion" $97.2 \%$ of respondents, according to the President, "the program of events dedicated to the 60th anniversary of the Universal Declaration of Human Rights," the draft decree indicates that they are aware of the media. Information about the judicial and legal reforms of respondents - $62.7 \% \mathrm{TV} 14.1 \%$ of the periodical press, radio $12.0 \%, 4.7 \%$ to relatives, friends, colleagues and neighbors, and $1.6 \%$ of the independent media can not [8; 207-208]. Clearly, the role of the media in the legal and educational activities, subject-object relations activities are always popular character anyway.

Obedience to the law, the product of legislative and regulatory impact, but it is only formed by the system of relations between subject and object. Regulatory and legal-normative beliefs and values of the subject as the subject of legal existence of the object are formed. Requires an active social and legal reality, have not yet been implemented, not reflected in the behavior of the person does what almost no renewal of the faith and of the knowledge society. This endeavor to resolve the conflict through lawyers, legal socialization. They say that the law socialization "on the one hand, social conditions and institutions in specific concepts and values of the cross to form a targeted, effective actions; on the other hand, the activities of man in the process of socialization, the process of its formation as a person. People working in the social environment, modification, improvement. Therefore, the process of socialization of human society and its impact on the internal spiritual world as an object. [9; 13].

For the creation of a democratic state of all citizens must be active in the social, legal. A person such activities require a complex task. Social effective legal, may appear active at all times. Rights activists, social It can be active at any time. Social activity rights activists as a "Chinese wall" or not, there are certain differences. For example; Social entrepreneurs active, but he did not know their rights and protection, always active Jarrett, a lawyer for the protection of his rights, contact a lawyer, a legal technology complexity, the current context of increased bureaucratic tasks to the defense business professional needs. Legal entity, its denial, it is also more money trying to find a comfortable lifestyle. In particular, those who committed the crime, and penal institutions will have the right to keep a good knowledge and you can not argue with specialists in this field. The point is not to defend the right to know and an active, but these efforts on the basis of what the goals and interests are.

Integration function refers to the legal culture of society, all the influences, knowledge, opinions and beliefs of legal behavior, however, are appropriate to lean on. Human phenomenon that individual and social embodies the qualities. Direct legal interest to conduct its compliance with the legal Dogmatism appreciated. He was always regarded as personal property, and be evaluated. However, this trait is also the influence of the social environment and society relationship drive.

Named one of the functions of culture, communication and socialization. Socialization, communicative function, communication, ties of socialization. The renewal of society based on democratic values and the communicative nature of the role and functions of socialization, the value increases. Legal culture can only transport them to the public, not to bring people of these functions loads of moral criteria. Communication one does not lead to productive results, socialization not the only criterion of activity. They are carrying the burden of a moral and spiritual values of people respectful.

The communicative function of the subjectobject communication between the state of the situation or to bring about this dialogue. Legal culture will appear in this communication. This classification of different forms of communication. But it is important for us is that the public and civil society in all subject-object relations in the relations between law and moral imperative to be open. Transparency of this dialogue is demand.

Legal culture is the most important aspect of its axiological nature, or social and legal values [10; 248-249]. Legal awareness and legal knowledge, 
legal conviction, and legal conduct, well, it enters into a legal culture, its attributes, it can be regarded as a legal value. Private embodies the culture of these components, but have a wide range of legal values. This approach is no word game or a tautology, not speculation. Most importantly, they are the reality, as the legal, social, political assets created, contributing to democratization of the society.

Democratic prognostic ideal, the goal is not reached its full state. Because the social, political, things will continue to improve the legal, historical, and cultural life as a long process. This is not the end, no one knows where the end, or something else. That this ideal is, without purposeful life stops, the community of democratic renewal to keep the portion of his life. This is the fate of it is sometimes considered to be the lowest in the world, be it social, political and legal before being aware of the weakness of his absolute dominion over the fact that this is tragic, but his "me" to create the look for the opportunity to live. Only in this way, is charged as an intelligent human intelligent creature proves that it has the right to live. Only in this manner its activities, search, beliefs, and life in general higher values.
These updates are possible only on the basis of legal culture. There the social democratic and social existences are reflected. Since independence, the process of social transformation of mind.

\section{Conclusion}

According to the researchers, the results of his study S.Norqulov, changes in the social transformation of mind paradigm based on the use of national and universal values and taking place. These factors include the impact of globalization and innovation, he added. Their socio-political sphere, the fixation of the principles of democracy and constitutionalism to join the market economy and global economic integration is taking place, the rule of spiritual and cultural values in the area of human body becomes, in the field of information technology-Internet and the global introduction of technological means of communication in the field of education, colleges, high schools, higher education institutions are built, may be an example of international public diplomacy transnational corporations expanding $[11 ; 162]$. These changes are also taking place in the society of democratic result.

\section{References:}

1. Boboev XB, Xamroev T, Alimasov V (2001) Madaniyatshunoslik - Toshkent: YAngi asr avlodi, 2001.-238 p.

2. Tozhihonov U, Saidov A (1998) Хиқиқіу madaniyat nazariyasi. 2-t. Toshkent: IIV Akademiyasi, 1998.-288 p.

3. Nasriddinova OT (2007) Yoshlar хиқиқіу madaniyatini yuksaltirish fuқarolik zhamiyatini shakllantirishning xal қiluvchi omili sifatidaToshkent: TDYUU, 2007-88 p.

4. Nishonova NR (2013) Davlat boshқаruvi tizimida hotin-қizlarning izhtimoiy-siyosiy faoliyati (falsafiy taxlil) -Toshkent: Fan, 2013.$224 \mathrm{p}$.

5. Karimov IA (2014) Uzbekiston erishgan уutuқ va marralar - biz tanlagan isloxotlar yy̆lining tasdifidir. T.22-Toshkent: Uzbekiston, 2014$368 \mathrm{p}$.

6. (2016) Наاқ sy̆zi, 2016, dec.8.
7. Tozhihonov U, Saidov A (1998) Хиқиқіу madaniyat nazariyasi. T.1. Toshkent: IIV Akademiyasi, 1998.-382 p.

8. Mamatov H (2009) Хиқиқіу madaniyat va Y̌zbekistonda fukarolik zhamiyatining shakllanish muommolari - Toshkent: "YURIST MEDIA MARKAZI " nashr, 2009.$256 \mathrm{p}$.

9. Soburov N (2011) Fuқarolarning хиқиқіу hulқatvorini shakllantirish muommolari (nazariya va amaliyot). Yuridik fan. nomzodi... diss. Avtoreferati. - Toshkent: 2011.-21 p.

10. Musaev F (2007) Demokratik davlat kurishning falsafiу-хиқиқіy asoslari- Toshkent Y̌zbekiston, 2007.-272 p.

11. Norқulov S (2015) Fuқarolik zhamiyati va izhitmoiy ongda transformaciya zharayonlariToshkent: Navro'z, 2015. -130p. 